\title{
Effect of sowing time on productivity of Bt and non Bt cotton under climate change
}

\author{
K Sankaranarayanan ${ }^{1}$, A H Prakash ${ }^{1}$ and K Rajendran ${ }^{2^{*}}$ (D)
}

\begin{abstract}
Background: Climate change affects cotton production systems in multiple ways, and the impacts are expected to influence the national economy of India. The weather conditions prevailing during squaring, flowering and boll development stages determine the seed cotton yield. The needs for adaptation connected to optimizing the timing of critical growth stages to minimize stresses and enhance resource utilization. The adjusting of sowing times proved to be an important management technique for improving seed cotton yield.

Results: The combined results for 3 years revealed that seed cotton yield was not influenced significantly by genotypes and interaction effect. However, the effect of date of sowing was significant. The best date of sowing was on 28 July which recorded the highest significant mean seed cotton yield ( $24.8 \mathrm{q} / \mathrm{ha})$ compared with other sowing dates.
\end{abstract}

Conclusions: Three years results of experiments show that the best date for sowing is 28 July which is optimum to realize higher productivity and profitability. Sowing window of cotton was re-standardized as from 21 July to 18 August. The existing recommendation of sowing window is 1 August to 31 August.

Keywords: Climate change, Dates of sowing, Bt and non-Bt cotton, Seed cotton yield

\section{Background}

India is considered one of the largest countries in the world for cotton cultivation area. The area is estimated at 12.3 million hectares; it is grown by nearly 6 million farmers. Cotton is the major cash crop of India and accounts for $75 \%$ of the fibre used in the textile industry which has 1500 spinning mills and accounts for $4 \%$ of the gross domestic product (GDP). Cotton impacts the lives of an estimated 60 million people in India, including farmers who cultivate the crop, and a legion of workers involved in the cotton industry from processing to trading. The impact of climate change on cotton crop is gaining momentum because of its association with the national economy and providing livelihood security to 60 million people including all stakeholders of the cotton value chain (Sankaranarayanan et al. 2010). The

\footnotetext{
* Correspondence: kr_agro@rediffmail.com

${ }^{2}$ Institute of Agriculture, National Pulses Research Centre, Tamil Nadu

Agricultural University, Vamban 622303, India

Full list of author information is available at the end of the article
}

changing climate has threatened the productivity of the agriculture sector making it vulnerable both economically and physically to climate unevenness and change. Productivity is being affected by many climate change variables including rainfall, high temperature, changes in sowing and harvesting dates, water availability and land suitability (Balathandayutham and Mayilswami 2015). Climate change may not have huge overall effects but regional effects are more extensive. Analysis of long-term weather data of Tamil Nadu found that the minimum temperature has increased significantly in Coimbatore while the same has decreased at Vellore whereas both minimum and maximum temperatures have increased at Madurai. South-west monsoon has decreased with decreased dispersion while north-east monsoon has increased with increased dispersion (Jayakumar Varadan et al. 2017). Further, the incoherence of climate change by heating necessitates devising adaptation strategies to overcome the adverse impacts of climate change. Cotton is very specific to its climatic requirements and reacts 
unfavourably for any shift from optimum weather factors. Cotton is considered one of the most crops affected by environmental, climatic conditions and sowing seasons compared to wheat and rice (Bradow and Davidonis 2000). Variable sowing time is mostly dependent upon climate, species specificity and agro-climate (rainfed vs. irrigated). Interaction of genotypes and date of sowing is an important strategy to analyse crop yield and quality environment (Campbell and Jones 2005). Therefore, genotype selection and suitable sowing date are important factors that can have a large impact on the yield of cotton crop (Delo et al. 2012). There are two facts that mostly limit cotton growth, yield and quality as growth is a function of product of genotypes and environment (Zeng et al. 2014). Optimum sowing time for different genotypes varies with regions depending on the environmental conditions of the area. Most favourable sowing time provides favourable situation for adequate crop growth as it escorts to the realization of the productivity potential of the crop (Sankaranarayanan et al. 2011a). To achieve the goal of the research, an experiment was conducted to optimize the best times for sowing two varieties of cotton cultivated in winter.

\section{Methods}

A field trial was conducted under irrigated condition at New Area farm of ICAR-Central Institute for Cotton Research, Regional station, Coimbatore, Tamil Nadu, India, during the fall season consecutively in 3 years (August to March) of 2014-2015, 2015-2016 and 2016-2017. The soil was clay loam in texture, low in available $\mathrm{N}(175 \mathrm{~kg} / \mathrm{ha})$, medium in available $\mathrm{P}$ $(14 \mathrm{~kg} / \mathrm{ha})$ and high in available $\mathrm{K}(532 \mathrm{~kg} / \mathrm{ha})$ with a $\mathrm{pH} 8.6$ and EC $0.3 \mathrm{dSm}^{-1}$. Soil test on micronutrient showed $0.50,1.3,2.6,2.3$ and $0.07 \mathrm{ppm}$ of DTPAextractable zinc, copper, manganese, iron and boron (hot water extract), respectively (Table 1 ).
The treatments comprised of nine dates of sowing (21 July, 28 July, 4 August, 11 August, 18 August, 25 August, 1 September, 8 September and 15 September) and two genotypes (Mallika BGII and Suraj non-Bt) were tried in factorial randomized block design with three replications. The recommended dose of $45 \mathrm{~kg}$ of $\mathrm{N}, 45 \mathrm{~kg}$ of $\mathrm{P}_{2} \mathrm{O}_{5}$ and $45 \mathrm{~kg}$ of $\mathrm{K}_{2} \mathrm{O}$ per hectare was applied to all the treatments and the remaining $45 \mathrm{~kg}$ of $\mathrm{N}$ per ha was top-dressed at the time of earthing up. Other cultivation practices were adopted uniformly for all the treatments. Pre-emergence application of pendimethalin $1 \mathrm{~kg}$ a.i./ha was also applied on the plots followed by two hands weeding to keep the experimental plot weed-free. Growth attributes, yield parameters and seed cotton yield were recorded during the course of the investigation. Fibre quality parameters viz. $2.5 \%$ span length, maturity ratio, uniformity ratio, micronaire, fibre strength and fibre elongation were also analysed. The quality parameters were analysed by using high-volume instruments (HVI, Statex- Fibrotex model). Growing degree days (GDD) is an arithmetic accumulation of daily mean temperature above the threshold temperature. It is computed using the formula $\left(\mathrm{GDD}\left({ }^{\circ} \mathrm{C}\right)=((\right.$ Maximum temperature $\left({ }^{\circ} \mathrm{C}\right)+$ Minimum temperature $\left.\left.\left({ }^{\circ} \mathrm{C}\right)\right) / 2\right)$ $15.5)$ given by Iwata (1984). Relative temperature disparity (RTD) is calculated using the formula of RTD = ((Maximum temperature $\left({ }^{\circ} \mathrm{C}\right)$ - Minimum temperature $\left({ }^{\circ} \mathrm{C}\right)$ )/Maximum temperature $\left.\left({ }^{\circ} \mathrm{C}\right)\right) \times 100$. The relative humidity difference between the morning and evening values is considered for calculating the RHD for the cropping period $(\mathrm{RHD}=(($ Morning $\mathrm{RH}(\%)-$ Evening $\mathrm{RH}(\%)$ )/Morning $\mathrm{RH}(\%)) \times 100$. Combined analysis was made from 3 years data to assess the effect of time of sowing of Bthybrid and non-Bt straight variety on growth characters, yield attributes, yield, quality and other parameters. Economics was also calculated on the basis of the prevailing market price of inputs and outputs. The prediction equation developed by multiple

Table 1 Mechanical and chemical analysis of the experimental soil

\begin{tabular}{lll}
\hline Components & Soil properties & Methods used \\
\hline Soil pH $(1: 2)$ & 8.6 & Glass electrode pH metre method (Jackson 1973) \\
EC $\left(\mathrm{dSm}^{-1}\right.$ at $\left.25.8^{\circ} \mathrm{C}\right)$ & 0.3 & Conductivity bridge method (Richards 1954) \\
Available $\mathrm{N}(\mathrm{kg} / \mathrm{ha})$ & 175.0 & Alkaline permanganate method (Subbiah and Asija 1956) \\
Available P $(\mathrm{kg} / \mathrm{ha})$ & 14.0 & Olsen method (Olsen et al. 1954) \\
Available K $(\mathrm{kg} / \mathrm{ha})$ & 532.0 & Flame photometric method (Jackson 1973) \\
$\begin{array}{l}\text { DTPA-extractable }(\mathbf{p p m}) \\
\text { Zinc }\end{array}$ & 0.50 & DTPA-extractable zinc, copper, manganese, iron (Lindsay and \\
Copper & 1.3 & Norvell 1978) and boron (hot water extract) (Berger and Truog 1939), respectively \\
Manganese & 2.6 & \\
Iron & 2.3 & \\
Boron & 0.07 & \\
\hline
\end{tabular}


regression analysis is yield $(\mathrm{q} / \mathrm{ha})=120.4-0.035 \mathrm{RTD}$ (0-60 days) - 0.039 RTD (61-130 days $)+0.019$ RHD (61-130 days) $+0.013 R F(61-130$ days $)-0.01 S S H$ (61130 days) (1) used for comparison.

\section{Results}

\section{Growth characters}

Biometric data collected at harvest revealed that growth characters consist of plant height $(\mathrm{cm})$, number of bolls, number of monopodia and sympodia which were influenced significantly by genotypes and different dates of sowing except plant height and monopodia by dates of sowing (Tables 2 and 3). The results further revealed that LAI were not influenced significantly by genotypes and different dates of sowing. The significant effect of interaction genotypes and sowing date was not observed. Superiority of Mallika BGII was the mean significantly tallest plant $(102.2 \mathrm{~cm})$, number of bolls (28.8), number of monopodia (1.8) and number of sympodia (19.3). Date of sowing 28th of July registered the significant highest number of nodes (25.8) number of bolls (32.1) and sympodia (20.5) at harvest, which was on par with 21 July, 4 Aug., 11 Aug and 18 Aug. The highest record of plant height ( $(102.2 \mathrm{~cm})$, number of bolls $(28.8)$, number of monopodia (1.8) and number of sympodia (19.3) was observed with Mallika BGII. Amongst different dates of sowing, 28th of July registered significantly the highest number of nodes (25.8), number of bolls (32.1) and sympodia (20.5) at harvest, which was on par with 21 July, 4 August, 11 August and 18 August.

\section{Yield attributes}

Data in Table 4 revealed that boll weight $(\mathrm{g})$ was influenced significantly by genotypes only. The results combined data revealed that the number of bursted bolls was influenced significantly by genotypes and different dates of sowing. There were no significant effects on the interaction between genotypes and sowing dates. It was also observed that Mallika BGII cultivar significantly surpassed in the number of busted bolls (24.0) and boll weight $(4.5 \mathrm{~g})$ at harvest, whereas Suraj cultivar recorded the number of bursted bolls of 16.2 and boll weight of $4.1 \mathrm{~g}$. The significantly highest number of bursted bolls (25.4) was recorded on 28 July sowing, which was on par with 21 July (22.1), 4 August (24.9), 11 August (23.2) and 18 August (22.2), and thus was reduced significantly by late sowing treatments beyond optimum times of sowing.

\section{Seed cotton yield}

Seed cotton yield was not influenced significantly by genotypes in combined data for 3 years. However, contrary to the above result, the significant differences were observed between genotypes in 20152016. Seed cotton yield differed with different cropping years (2014-2015, 2015-2016 and 2016-2017) and poor performance was noticed especially with 2016-2017 (Fig. 1). Seed cotton yield was significantly influenced by dates of sowing. Amongst different dates of sowing, sowing on 4 August (30.9 q/ha) recorded that highest significantly seed cotton yield in 2014-2015 which was on par with 28 July $(28.0$ q/ ha), 21 July (26.8 q/ha), 11 August (27.7 q/ha), 18 August (26.4 q/ha) and 25 August (24.3 q/ha). In

Table 2 Growth characters as influenced by genotypes and date of sowing at harvest

\begin{tabular}{|c|c|c|c|c|c|c|c|c|c|}
\hline \multirow{2}{*}{$\begin{array}{l}\text { Date of } \\
\text { sowing }\end{array}$} & \multicolumn{3}{|c|}{ Plant height (cm) } & \multicolumn{3}{|c|}{ No. of nodes } & \multicolumn{3}{|c|}{ No. of Bolls } \\
\hline & Mallika & Suraj & Mean & Mallika & Suraj & $\overline{\text { Mean }}$ & Mallika & Suraj & Mean \\
\hline 21 July & 108.2 & 82.7 & 95.5 & 28.3 & 23.3 & 24.8 & 37.3 & 23.3 & 30.3 \\
\hline 28 July & 112.6 & 91.1 & 101.9 & 26.0 & 23.7 & 25.8 & 37.9 & 26.4 & 32.1 \\
\hline 4 August & 105.0 & 85.0 & 95.0 & 26.1 & 22.8 & 24.5 & 35.4 & 22.2 & 28.8 \\
\hline 11 August & 111.6 & 91.4 & 101.5 & 24.3 & 22.4 & 23.4 & 30.8 & 23.6 & 27.2 \\
\hline 18 August & 98.1 & 86.4 & 92.3 & 24.1 & 21.3 & 22.7 & 29.2 & 21.6 & 25.4 \\
\hline 25 August & 97.8 & 94.7 & 96.3 & 23.3 & 22.2 & 22.7 & 24.3 & 16.6 & 20.5 \\
\hline $1 \mathrm{Sep}$ & 93.3 & 88.1 & 90.7 & 22.8 & 20.9 & 21.8 & 24.2 & 16.0 & 20.1 \\
\hline 8 Sep & 98.6 & 88.9 & 93.7 & 23.5 & 20.2 & 21.9 & 21.9 & 15.1 & 18.5 \\
\hline 15 Sep & 94.4 & 93.9 & 94.2 & 21.7 & 20.3 & 21.0 & 18.0 & 12.0 & 15.0 \\
\hline Mean & 102.2 & 89.1 & 95.7 & 24.5 & 21.9 & 23.2 & 28.8 & 19.7 & 24.2 \\
\hline ANOVA & DXG & Genotype & DOS & DXG & Genotype & DOS & DXG & Genotype & DOS \\
\hline S.Ed & 10.3 & 3.4 & 7.3 & 1.6 & 0.6 & 1.2 & 4.7 & 1.5 & 4.2 \\
\hline CD (0.05) & NS & 7.0 & NS & NS & 1.1 & 2.4 & NS & 3.2 & 7.3 \\
\hline$N S / S$ & & & & & & & & & \\
\hline
\end{tabular}


Table 3 Growth characters as influenced by genotypes and date of sowing at harvest

\begin{tabular}{|c|c|c|c|c|c|c|c|c|c|}
\hline \multirow{2}{*}{$\begin{array}{l}\text { Date of } \\
\text { sowing }\end{array}$} & \multicolumn{3}{|c|}{ Monopodia } & \multicolumn{3}{|c|}{ Sympodia } & \multicolumn{3}{|l|}{ LAI } \\
\hline & Mallika & Suraj & Mean & Mallika & Suraj & Mean & Mallika & Suraj & Mean \\
\hline 21 July & 2.2 & 1.0 & 1.6 & 22.4 & 18.6 & 20.2 & 2.0 & 1.9 & 1.9 \\
\hline 28 July & 2.0 & 1.7 & 1.8 & 22.0 & 18.3 & 20.5 & 1.8 & 2.3 & 2.0 \\
\hline 4 August & 1.9 & 1.1 & 1.5 & 19.6 & 17.3 & 18.5 & 2.4 & 2.1 & 2.3 \\
\hline 11 August & 2.1 & 1.4 & 1.7 & 19.6 & 18.0 & 18.8 & 2.0 & 1.6 & 1.8 \\
\hline 18 August & 2.0 & 1.4 & 1.7 & 19.6 & 17.0 & 18.3 & 2.1 & 1.6 & 1.8 \\
\hline 25 August & 1.6 & 1.2 & 1.4 & 18.4 & 18.2 & 18.3 & 1.1 & 1.8 & 1.4 \\
\hline $1 \mathrm{Sep}$ & 1.6 & 1.2 & 1.4 & 17.5 & 17.3 & 17.4 & 1.2 & 1.4 & 1.3 \\
\hline 8 Sep & 1.5 & 1.0 & 1.3 & 17.8 & 17.2 & 17.5 & 1.4 & 1.5 & 1.4 \\
\hline $15 \mathrm{Sep}$ & 1.3 & 1.0 & 1.2 & 16.4 & 17.6 & 17.0 & 1.7 & 1.7 & 1.7 \\
\hline Mean & 1.8 & 1.2 & 1.5 & 19.3 & 17.7 & 18.5 & 1.7 & 1.7 & 1.0 \\
\hline ANOVA & DXG & Genotype & DOS & DXG & Genotype & DOS & DXG & Genotype & DOS \\
\hline S.Ed & 0.4 & 0.1 & 0.3 & 1.7 & 0.6 & 1.0 & 0.8 & 0.3 & 0.6 \\
\hline$C D(0.05)$ & NS & 0.3 & NS & 3.4 & 1.2 & 2.2 & NS & NS & NS \\
\hline
\end{tabular}

2015-2016, 28 July sowing registered significantly the highest seed cotton yield (31.07 q/ha) which was on par with 21 July (30.17 q/ha),4 August (25.66 q/ha) and 18 August (26.19 q/ha). The similar trend of 2015-2016 result was observed in 2016-2017 and the combined data also. In 2016-2017, it was found that 28 July sowing registered significantly the highest seed cotton yield $(15.5 \mathrm{q} / \mathrm{ha})$ which was on par with 21 July (13.2 q/ha), 4 August (13.7 q/ha) and 11 August (13.1 q/ha). The results of 3 years combined reported that amongst different dates of sowing, 28 July sowing $(24.8 \mathrm{q} / \mathrm{ha})$ registered significantly the highest mean seed cotton yield which was on par with 21 July (23.4 q/ha), 4 August (23.4 q/ha), 11 August (21.9 q/ha) and 18 August (20.9 q/ha) (Table 3). The significant interaction effect was not observed between genotypes and a different date of sowing throughout the course of investigation.

\section{Economics}

Data presented in Table 5 revealed that the cost of cultivation ( $₹ / h a)$, gross return $(₹ / h a)$ and net return ( $₹ / h a)$ were significantly influenced by date of sowing in all 3 years of experimentation. The significant highest cost of cultivation ( $₹ 51,650 / \mathrm{ha}$ ), gross return (₹112,294/ha) and net return (₹60,642/ha) were calculated with 4 August of sowing which was on par with 21 July, 28 July, 11 August, 18 August and 25 August in 2014-2015. In 2015-

Table 4 Seed cotton yield ( $q / h a)$ and yield attributes as influenced by genotypes and date of sowing

\begin{tabular}{|c|c|c|c|c|c|c|c|c|c|}
\hline \multirow{2}{*}{$\begin{array}{l}\text { Date of } \\
\text { sowing }\end{array}$} & \multicolumn{3}{|c|}{ Seed cotton yield (q/ha) } & \multicolumn{3}{|c|}{ Boll weight } & \multicolumn{3}{|c|}{ No. of bursted bolls/plant } \\
\hline & Mallika & Suraj & $\overline{\text { Mean }}$ & Mallika & Suraj & $\overline{\text { Mean }}$ & Mallika & Suraj & $\overline{\text { Mean }}$ \\
\hline 21 July & 24.2 & 22.5 & 23.4 & 4.4 & 4.2 & 4.3 & 30.3 & 20.4 & 25.4 \\
\hline 28 July & 26.5 & 23.2 & 24.8 & 4.5 & 4.1 & 4.3 & 22.8 & 21.3 & 22.1 \\
\hline 4 August & 24.3 & 22.5 & 23.4 & 4.6 & 4.1 & 4.4 & 30.3 & 19.5 & 24.9 \\
\hline 11 August & 22.8 & 21.0 & 21.9 & 4.5 & 4.2 & 4.4 & 27.8 & 18.6 & 23.2 \\
\hline 18 August & 21.8 & 20.0 & 20.9 & 4.4 & 4.0 & 4.2 & 26.7 & 17.7 & 22.2 \\
\hline 25 August & 18.1 & 15.4 & 16.7 & 4.5 & 4.1 & 4.3 & 22.9 & 14.0 & 18.4 \\
\hline 1 Sep & 17.6 & 15.1 & 16.3 & 4.5 & 4.1 & 4.3 & 21.7 & 13.8 & 17.8 \\
\hline 8 Sep & 15.4 & 12.7 & 14.1 & 4.4 & 4.0 & 4.3 & 19.6 & 12.0 & 15.8 \\
\hline 15 Sep & 10.5 & 9.1 & 9.8 & 4.3 & 4.1 & 4.2 & 14.3 & 8.7 & 11.5 \\
\hline Mean & 20.1 & 17.9 & 10.8 & 4.5 & 4.1 & 1.4 & 24.0 & 16.2 & 20.1 \\
\hline ANOVA & $D X G$ & Genotype & DOS & $D \times G$ & Genotype & DOS & $D \times G$ & Genotype & DOS \\
\hline S.Ed & 3.5 & 1.2 & 2.5 & 0.3 & 0.1 & 0.2 & 3.5 & 1.2 & 2.5 \\
\hline CD (0.05) & NS & NS & 5.2 & NS & 0.2 & NS & NS & 2.4 & 5.1 \\
\hline
\end{tabular}




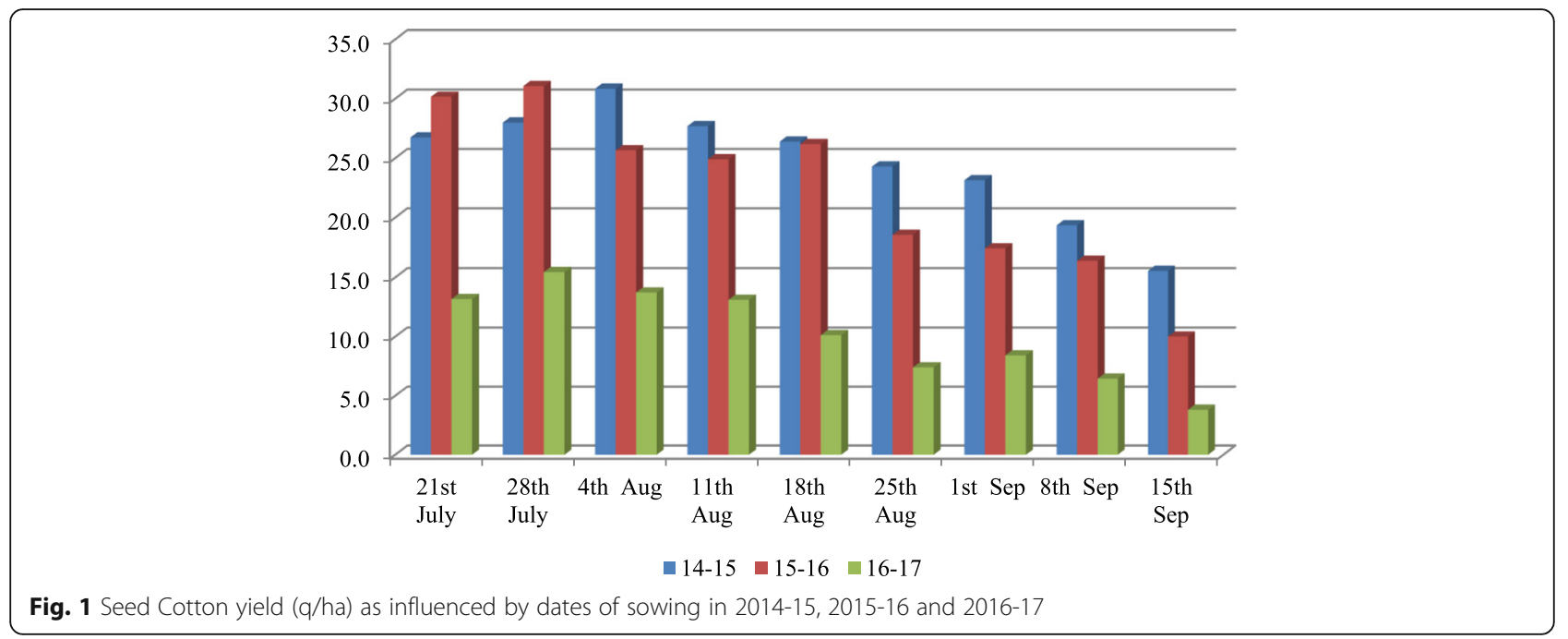

2016, the significantly highest cost of cultivation (₹52, $570 /$ ha), gross return (₹146,142/ha) and net return (₹93,572/ha) were calculated with 28 July of sowing which was on par with 21 July, 28 July, 11 August and 18 August. A similar trend of 2015-2016 was observed in 2016-2017; cost of cultivation, gross return and net return were highly significantly registered with 28 July of sowing which was on par with 21 July, 28 July, 4 August and 11 August. The 3 years of combined analysis revealed that the significant highest combined mean of cost of cultivation ( $₹ 47,722 / \mathrm{ha}$ ), gross return ( $₹ 111,561$ / ha) and net return (₹63,839/ha) were calculated with 28 July of sowing, which was on par with 21 July, 4 August, 11 August and 18 August (Table 5).

\section{Weather parameters}

Identification of yield influencing weather parameters/indices is one of the objectives of the trail. The seed cotton yield was correlated with relative temperature disparity (RTD), relative humidity maximum (RH I), relative humidity minimum (RH II), crop evapotranspiration (ETC), maximum and minimum temperature, sunshine hours (SSH) and rainfall for different growth periods of $0-60$ (vegetative) and 61-130 DAS (reproductive) (Table 8). The correlation values were tested with $T$ test to assess the significance of correlation. The significant positive correlation was noticed with minimum temperature, rainfall and GDD of reproductive periods and rainfall and ETC of vegetative periods in all 3 years. The negative correlation of

Table 5 Economics as influenced by genotypes and dates of sowing

\begin{tabular}{|c|c|c|c|c|c|c|c|c|c|}
\hline \multirow{2}{*}{$\begin{array}{l}\text { Date of } \\
\text { sowing }\end{array}$} & \multicolumn{3}{|c|}{ Cost of cultivation (Rs/ha) } & \multicolumn{3}{|c|}{ Gross return (Rs/ ha) } & \multicolumn{3}{|c|}{ Net rReturn (Rs/ha) } \\
\hline & Mallika & Suraj & Mean & Mallika & Suraj & Mean & Mallika & Suraj & $\overline{\text { Mean }}$ \\
\hline 21 July & 46,937 & 45,398 & 46,168 & 102,409 & 103,983 & 104,476 & 55,472 & 58,585 & 58,309 \\
\hline 28 July & 49,358 & 46,085 & 47,722 & 112,994 & 107,357 & 111,561 & 63,636 & 61,272 & 63,839 \\
\hline 4 August & 47,159 & 45,318 & 46,238 & 101,954 & 101,904 & 103,454 & 54,794 & 56,586 & 57,215 \\
\hline 11 August & 45,581 & 43,833 & 44,707 & 95,566 & 96,265 & 97,320 & 49,984 & 52,432 & 52,613 \\
\hline 18 August & 44,542 & 42,676 & 43,609 & 90,598 & 91,163 & 92,260 & 46,056 & 48,487 & 48,651 \\
\hline 25 August & 40,728 & 37,998 & 39,363 & 73,418 & 68,924 & 72,496 & 32,690 & 30,927 & 33,133 \\
\hline 1 Sep & 40,195 & 37,745 & 38,970 & 71,566 & 68,285 & 71,186 & 31,372 & 30,540 & 32,216 \\
\hline 8 Sep & 38,005 & 35,282 & 36,644 & 63,511 & 56,849 & 61,190 & 25,505 & 21,567 & 24,546 \\
\hline 15 Sep & 32,968 & 31,600 & 32,284 & 41,851 & 39,963 & 41,732 & 8883 & 8362 & 9,448 \\
\hline Mean & 42,830 & 40,659 & 41,745 & 83,763 & 81,633 & 83,964 & 40,933 & 40,973 & 42,219 \\
\hline ANOVA & DXG & Genotype & DOS & DXG & Genotype & DOS & DXG & Genotype & DOS \\
\hline S.Ed & 5068 & 1671 & 3648 & 15,469 & 5090 & 11,139 & 13,219 & 4361 & 9512 \\
\hline CD (0.05) & NS & NS & 7335 & NS & NS & 22,363 & NS & NS & 19,152 \\
\hline
\end{tabular}




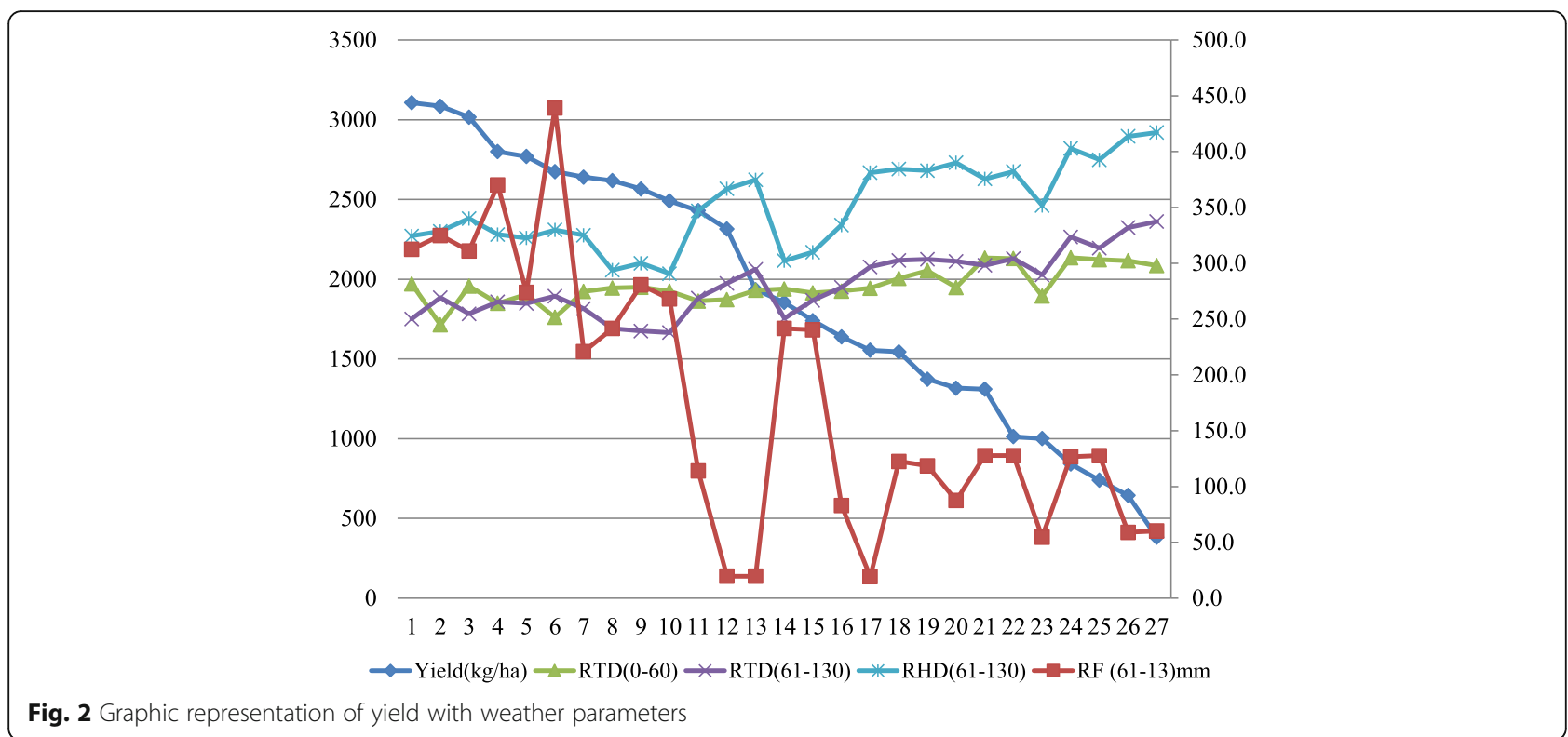

rainfall and RTD during vegetative growth and RTD and RHD during reproductive periods is in all 3 years (Table 8). The combined analysis found that minimum temperature, morning and relative humidity and rainfall were positively and significantly correlated with seed cotton yield. The significant negative correlation was observed with RTD for both vegetative and reproductive growth periods and RHD of reproductive period (Table 9 and Fig. 2)

\section{Quality characters}

The increase in productivity alone could not be a benefit for the cotton growers as the quality of cotton fibre is the primary concern for fetching a higher price. Lint samples analysed by HVI to assess the quality of characters revealed that these were influenced little by genotypes (except strength $(\mathrm{g} / \mathrm{tex}))$ or planting time (Tables 6 and 7). The combined results revealed that Suraj had a significantly higher fibre strength than Mallika BGII.

\section{Discussion}

\section{Growth characters}

Growth characters include plant height $(\mathrm{cm})$, number of bolls, number of monopodia and sympodia which were influenced significantly by genotypes and different dates of sowing. The highest significant record of the tallest plant $(102.2 \mathrm{~cm})$, number of bolls (28.8), number of monopodia (1.8) and number of sympodia (19.3) were

Table 6 Quality parameters as influenced by genotypes and dates of sowing

\begin{tabular}{|c|c|c|c|c|c|c|c|c|c|}
\hline \multirow{2}{*}{$\begin{array}{l}\text { Date of } \\
\text { sowing }\end{array}$} & \multicolumn{3}{|c|}{$2.5 \%$ span length ( $\mathrm{mm}$ ) } & \multicolumn{3}{|c|}{ Uniformity ratio } & \multicolumn{3}{|c|}{ Micronaire } \\
\hline & $\overline{\text { Mallika }}$ & Suraj & $\overline{\text { Mean }}$ & $\overline{\text { Mallika }}$ & Suraj & $\overline{\text { Mean }}$ & $\overline{\text { Mallika }}$ & Suraj & $\overline{\text { Mean }}$ \\
\hline 21 July & 30.4 & 30.6 & 30.5 & 46.8 & 46.3 & 46.5 & 4.1 & 4.1 & 4.1 \\
\hline 28 July & 29.9 & 30.8 & 30.3 & 47.1 & 46.4 & 46.8 & 4.2 & 4.3 & 4.2 \\
\hline 4 August & 30.0 & 30.5 & 30.3 & 46.7 & 46.1 & 46.4 & 4.0 & 4.3 & 4.2 \\
\hline 11 August & 30.3 & 30.4 & 30.3 & 46.5 & 46.7 & 46.6 & 4.2 & 4.2 & 4.2 \\
\hline 18 August & 30.5 & 31.0 & 30.8 & 46.2 & 46.2 & 46.2 & 4.0 & 4.1 & 4.0 \\
\hline 25 August & 30.5 & 30.4 & 30.4 & 46.6 & 46.4 & 46.5 & 4.1 & 4.3 & 4.2 \\
\hline $1 \mathrm{Sep}$ & 30.2 & 30.7 & 30.5 & 46.7 & 46.5 & 46.5 & 4.0 & 4.3 & 4.1 \\
\hline 8 Sep & 30.6 & 31.5 & 31.1 & 46.4 & 46.1 & 46.3 & 4.1 & 4.1 & 4.1 \\
\hline 15 Sep & 30.7 & 31.2 & 31.0 & 46.7 & 46.3 & 46.5 & 3.8 & 3.8 & 3.8 \\
\hline Mean & 30.3 & 30.8 & 30.6 & 46.6 & 46.4 & 46.5 & 4.0 & 4.2 & 4.1 \\
\hline ANOVA & DXG & Genotype & DOS & DXG & Genotype & DOS & DXG & Genotype & DOS \\
\hline S.Ed & 0.9 & 0.3 & 0.7 & 0.6 & 0.2 & 0.4 & 0.3 & 0.1 & 0.2 \\
\hline CD (0.05) & 1.8 & 0.6 & 1.51 & 1.2 & 0.4 & 0.81 & 0.5 & 0.2 & 0.4 \\
\hline
\end{tabular}


Table 7 Quality parameters as influenced by genotypes and dates of sowing

\begin{tabular}{|c|c|c|c|c|c|c|}
\hline \multirow{2}{*}{$\begin{array}{l}\text { Date of } \\
\text { sowing }\end{array}$} & \multicolumn{3}{|c|}{ Strength (g/tex) } & \multicolumn{3}{|c|}{ Elongation (\%) } \\
\hline & Mallika & Suraj & Mean & Mallika & Suraj & Mean \\
\hline 21 July & 22.2 & 22.8 & 22.5 & 5.8 & 5.9 & 5.9 \\
\hline 28 July & 22.1 & 23.1 & 22.6 & 5.8 & 5.9 & 5.8 \\
\hline 4 August & 22.1 & 22.2 & 22.1 & 5.8 & 5.9 & 5.9 \\
\hline 11 August & 21.6 & 22.5 & 22.1 & 5.7 & 5.9 & 5.8 \\
\hline 18 August & 22.7 & 22.6 & 22.7 & 5.7 & 5.9 & 5.8 \\
\hline 25 August & 21.9 & 22.1 & 22.0 & 5.7 & 5.9 & 5.8 \\
\hline $1 \mathrm{Sep}$ & 22.4 & 22.4 & 22.4 & 5.7 & 5.9 & 5.8 \\
\hline $8 \mathrm{Sep}$ & 21.8 & 24.2 & 23.0 & 5.7 & 6.0 & 5.9 \\
\hline 15 Sep & 22.0 & 23.4 & 22.7 & 5.8 & 5.9 & 5.8 \\
\hline Mean & 22.1 & 22.8 & 22.4 & 5.8 & 5.9 & 5.8 \\
\hline ANOVA & DXG & Genotype & DOS & DXG & Genotype & DOS \\
\hline S.Ed & 0.9 & 0.3 & 0.7 & 0.1 & 0.0 & 0.1 \\
\hline$C D(0.05)$ & 1.9 & 0.6 & 1.5 & 0.3 & 0.1 & 0.25 \\
\hline
\end{tabular}

observed with Mallika BGII. The differences in height were perhaps due to the differences in genetic makeup as reported by Hussain et al. (2007). The differences in the number of sympodial branches may also be attributed to differences in genetic materials of the genotypes used. In this concern, Bolonhezi et al. (2000) reported analogous results and attributed differences to their genetic makeup. Amongst different dates of sowing, 28 July registered the significant highest number of nodes (25.8), number of bolls (32.1) and sympodia (20.5) at harvest (Tables 2 and 3). The combined weather data reported that 28 July registered a high minimum temperature of $22^{\circ} \mathrm{C}$, high morning and evening relative humidity of (93.6 and 59.0\%) and high crop evapotranspiration of $(48.3 \mathrm{~mm})$ which were recorded at reproductive phase (61-130 DAS). During vegetative phase, high sunshine hours (7.1), low morning and evening relative humidity (83.9 and 53.5\%) and high crop evapotranspiration $(51.1 \mathrm{~mm})$ were recorded at vegetative phase $(1-60$ DAS). The prevalence of congenial weather conditions in the respective periods resulted in increased plant growth and greater vegetative and reproductive branches. Earlier studies also showed that the accumulated total solar radiation decreased as the sowing was delayed leading to a progressive drop in the growth characters in cotton crop (Gopalswamy et al. 1988). The optimum time planted cotton had accumulated more of its resources and assimilates in reproductive growth. Presumably, the early-planted cotton is able to take advantage of more favourable weather conditions than late-planted cotton (Pettigrew and Adamczyk 2006). Early sown crops had $32 \%$ more fruiting branches than the late-sown crops due to easy access to available resources early in the season (Khan et al. 2017).

\section{Yield attributes}

The results revealed that boll weight (g) was influenced significantly by genotypes. The significantly highest mean number of bursted bolls (24.0) and boll weight (4.5 g) at harvest was registered with Mallika BGII (Table 4). Suraj recorded 16.2 and $4.1 \mathrm{~g}$ of the number of busted bolls and boll weight. The gradual reduction in boll weight by late sowing was reported by Saroya et al. (1980), which was not observed in tested periods with these selected genotypes. The significant highest number of bursted bolls (25.4) was recorded with 28 July sowing. which was reduced significantly by late sowing treatments beyond optimum times of sowing. In the last sowing of 15 September, low minimum temperature $\left(22.7{ }^{\circ} \mathrm{C}\right)$, sunshine hours (6.2), high morning (93.3\%) and evening (57.3\%) relative humidity were recorded during vegetative stage (1-60 DAS). The same times of sowing registered low maximum $\left(29.6{ }^{\circ} \mathrm{C}\right)$ and minimum temperature $\left(20.4{ }^{\circ} \mathrm{C}\right)$, evening (54.3\%) relative humidity and rainfall $(19.9 \mathrm{~mm})$ during reproductive stage (61-130 DAS). The weather parameters recorded with last sowing was not conducive for cotton. Delayed planting usually reduces the number of bursted bolls due to delayed physiological maturity and carbohydrate deficiency (Gwathmey and Clement 2010). Delaying of planting pushed cotton plants for unfavourable weather for crop growth thus consistently decreases the number of open bolls (Elayan et al. 2015). Minimum temperature decreased in late sowing which did not favour proper boll maturation of seed cotton but promoted the pest population in late sowing treatments (Ali et al. 2004). Reddy (1992) observed that maximum boll production occurred at favourable mean air temperature of $30{ }^{\circ} \mathrm{C}$. Higher number of bolls in optimum sowing dates could be due to better environmental conditions like mean air temperature during the flowering and boll development period with enhanced photosynthesis. Yeates et al. (2013) reported that cooler night temperature might be detrimental to boll retention and growth. Further, the reduction in all the yield parameters in later sowing dates might be due to poor environmental conditions particularly minimum temperature falling at the time of reproductive stage (Lakkineni et al. (1994).

\section{Seed cotton yield}

Favourable climate during 2014-2015 and 2015-2016 resulted in higher seed cotton yield ( 30.9 and $31.1 \mathrm{q} / \mathrm{h}$ ) which are respectively by respective high-performing sowing treatments as compared to the less favourable year (2016-2017) recorded only (15.5 q/ha) despite the fact that the genotypes were repeated following similar management practices in all 3 years. The analysis of 
weather parameters found that higher seasonal rainfall received were 508.9 and $351.4 \mathrm{~mm}$ during 2014-2015 and 2015-2016, respectively, which influenced positively towards better crop growth and development that led to realization of higher yield. The high-performing sowing treatment received $134.7 \mathrm{~mm}$ of rainfall in the year of 2016-2017. Higher seasonal rainfall received had high positive correlation with seed cotton yield (Sankaranarayanan et al. 2011b).

The combined result revealed that between genotypes, Suraj registered less biometrics and yield attributes per plant basis; however, the seed cotton yield harvested was comparable with Mallika BGII because of the fact that higher population (29629/ha) of Suraja accommodated per unit area (recommended spacing of $75 \times 45 \mathrm{~cm}$ ) than Mallika BG II kept the population of 18,518/ha (as recommended spacing of $90 \times 60 \mathrm{~cm}$ ). The comparatively higher population of straight variety (Suraj) kept compensated the lower per plant yield and produced on par yield with BGII hybrid (Mallika BGII). Seed cotton yield was significantly influenced by dates of sowing. While in different dates of sowing, the results of 3 years of combined data reported that 28 July sowing $(24.8 \mathrm{q} / \mathrm{ha})$ registered significantly the highest mean seed cotton yield which was on par with 21 July (23.4 q/ha), 4 August (23.4 q/ha), $11 \mathrm{Au}$ gust (21.9 q/ha) and 18 August (20.9 q/ha) (Table 3). The higher ETC (99.4 mm), GDD (683.7) and low RTD (1659.5) recorded on 28 July favoured cotton growth and development. The further delay in sowing time led to yield decrease linearly and significantly. These variations in yield components could be further traced back to variations in growth and yield parameters. Significantly higher number of nodes, sympodia and bolls were recorded, whereas sowing beyond at 18 August fared poorly with growth and yield attributes. Khan et al. (2015) reported highly positive and significant relationship between growth attributes and plant yield. Favourable and conducive climate prevailed in the reported periods (21 July to 18 August) which might have helped for better vegetative and reproductive growth and seed cotton also. The reproductive development in late sown crop was affected by cooler temperature and low light, which reduced photosynthetic activity carbohydrates transition to fruit structures (Gormus and Yucel 2002; Liu et al. 2015; and Zhang et al. 2014). Bt hybrids trials conducted during spring season under All India Coordinated Research Project AICRP (Cotton) also revealed that timely planting of Bt cotton recorded $1.69 \mathrm{tha}^{-1}$ when compared with the delayed one $\left(1.39 \mathrm{tha}^{-1}\right)$ at Surat (AICCIP 2009) as delayed sowing normally reduces yield through shortening life-cycle of the crop due to unfavourable environmental factors at the reproductive stage. Pettigrew (2002) also observed that the early-planted cotton yielded $10 \%$ more lint than that produced by the late-planted cotton. The less yield was due to suboptimal weather conditions in late sowing date (Gormus and Yucel 2002).

\section{Economics}

The combined analysis for 3 years revealed that the significant highest combined mean of cost of cultivation ( $₹ 47,722 /$ ha), gross return ( $₹ 111,561 /$ ha) and net return (₹63,839/ha) were calculated with 28 July of sowing, which was on par with 21 July, 4 August, 11 August and 18 August (Table 5). The higher seed cotton yield recorded on 28 July by favourable climate in turn led to higher economic returns. As manual picking charges are contributing 40 to $50 \%$ of cost of cultivation, hence higher cost of cultivation was calculated with dates of sowing which registered higher yield in all 3 years.

\section{Weather parameters}

Cotton could suffer from $60 \%$ of the yield loss due to unfavourable climate alone as compared to $30 \%$ yield loss recorded in food crops viz. cereals, oilseeds and pulses (Dason et al. 1996). This huge loss in cotton is because of the fact that the climate influences not only the growth, development and reproductive activities of the crop, but also the occurrence and performance of pests, diseases, weeds, etc., besides imposing an impact on the nutrient availability and extractability of the cotton plants throughout the cropping season (Sankaranarayanan et al. 2011a). The combined analysis found that minimum temperature, morning relative humidity and rainfall were positively and significantly correlated with seed cotton yield. The

Table 8 Weather parameters of experimental years and 50 years of normal

\begin{tabular}{lllllllllll}
\hline Month & Max. $\left({ }^{\circ} \mathrm{C}\right)$ & Normal $\left({ }^{\circ} \mathrm{C}\right)$ & Min. $\left({ }^{\circ} \mathrm{C}\right)$ & Normal $\left({ }^{\circ} \mathrm{C}\right)$ & SSH & Normal SSH & RTD $(\%)$ & Normal RTD & GDD & Normal GDD \\
\hline July & 31.3 & 30.1 & 23.3 & 22.2 & 5.6 & 4.6 & 25.6 & 26.2 & 362.7 & 328.6 \\
Aug. & 31.7 & 30.1 & 23.1 & 22.2 & 7.0 & 5.8 & 27.2 & 26.2 & 365.8 & 328.6 \\
Sep. & 32.4 & 29.3 & 23.1 & 21.8 & 6.7 & 5.2 & 28.6 & 25.6 & 366 & 300.0 \\
Oct. & 31.4 & 31.6 & 22.7 & 21.4 & 6.3 & 6.3 & 27.8 & 32.3 & 353.4 & 337.9 \\
Nov. & 29.8 & 29.2 & 21.8 & 20.2 & 4.7 & 6.1 & 26.9 & 30.8 & 306 & 273.0 \\
Dec. & 29.3 & 29.4 & 21.2 & 17.9 & 5.2 & 8.7 & 27.4 & 39.1 & 300.7 & 251.1 \\
Jan. & 30.5 & 29.4 & 19.6 & 17.9 & 7.1 & 8.7 & 35.8 & 39.1 & 294.5 & 251.1 \\
\hline
\end{tabular}


Table 9 Seed cotton yield ( $\mathrm{q} / \mathrm{ha}$ ) correlation with weather parameters

\begin{tabular}{|c|c|c|c|c|c|}
\hline Parameters & $2014-2015$ & $2015-2016$ & $2016-2017$ & Combined & Combined (mean) \\
\hline $\operatorname{Max} V$ & NS & 0.839 & NS & NS & 0.735 \\
\hline $\operatorname{Max} R$ & NS & 0.824 & 0.827 & NS & 0.754 \\
\hline Min V & 0.888 & NS & 0.720 & NS & 0.930 \\
\hline Min R & 0.882 & 0.946 & 0.939 & 0.640 & 0.965 \\
\hline $\mathrm{RHIV}$ & -0.800 & NS & -0.828 & NS & -0.918 \\
\hline $\mathrm{RHIR}$ & 0.929 & NS & 0.816 & 0.787 & 0.860 \\
\hline RHIIV & -0.918 & -0.768 & NS & NS & -0.951 \\
\hline RHIIR & 0.944 & NS & 0.840 & 0.806 & 0.849 \\
\hline SSHV & 0.772 & 0.711 & NS & NS & 0.783 \\
\hline SSHR & NS & NS & NS & -0.663 & NS \\
\hline RFV & -0.818 & -0.867 & -0.696 & NS & -0.958 \\
\hline RFR & 0.810 & 0.875 & NS & 0.723 & 0.969 \\
\hline GDDV & NS & 0.924 & NS & NS & 0.656 \\
\hline GDDR & 0.741 & 0.940 & 0.915 & NS & 0.917 \\
\hline RTDV & -0.691 & 0.902 & NS & -0.733 & NS \\
\hline RTDR & -0.877 & -0.783 & -0.902 & -0.862 & -0.899 \\
\hline RHDV & NS & NS & NS & NS & NS \\
\hline RHDR & -0.920 & NS & -0.845 & -0.775 & -0.823 \\
\hline ETC V & 0.777 & 0.924 & 0.975 & NS & 0.982 \\
\hline ETCR & NS & 0.707 & NS & NS & NS \\
\hline
\end{tabular}

significant negative correlation was observed with RTD for both vegetative and reproductive growth periods and RHD of reproductive period (Table 9 and Fig. 2).

\section{Long-term weather parameter}

The reason for shift of dates of sowing from $15 \mathrm{Au}$ gust (existing recommendation) to 28 July was investigated by analysing the weather parameters, prevailed during the cropping periods (2014-2015, 2015-2016 and 2016-2017) in comparison to normal weathers (50 years average) (Tables 8, 9 and 10). Long-term climate analysis revealed an increase of maximum temperatures in Coimbatore district (Jayakumar Varadan et al. 2017). The mean maximum and minimum temperatures, respectively, of 31.3 and $23.3{ }^{\circ} \mathrm{C}$ were recorded in the month of July (experimental years) as

Table 10 Prevailed weather parameter in high performing treatments in different years

\begin{tabular}{|c|c|c|c|c|c|c|c|c|}
\hline Parameters & $\begin{array}{l}2014- \\
2015\end{array}$ & $\begin{array}{l}2015- \\
2016\end{array}$ & $\begin{array}{l}2016- \\
2017\end{array}$ & $\begin{array}{l}\text { CV } \\
(\%)\end{array}$ & DOS & $\begin{array}{l}\text { No of days advanced/ } \\
\text { delayed }\end{array}$ & $\begin{array}{l}\text { Actual mean yield ( } q \text { / } \\
\text { ha) }\end{array}$ & $\begin{array}{l}\text { Estimated yield (q/ } \\
\text { ha) }\end{array}$ \\
\hline $\begin{array}{l}\text { Yield (q } \\
\mathrm{ha}^{-1} \text { ) }\end{array}$ & 30.85 & 31.07 & 15.45 & 34.7 & 21 July & 7 & 23.4 & 23.7 \\
\hline Max & 30.5 & 31.3 & 32 & 2.4 & 28 July & 0 & 24.8 & 25.7 \\
\hline Min & 22.2 & 23 & 22.5 & 1.9 & 4 Aug & 7 & 23.4 & 23.7 \\
\hline RHI & 95.2 & 87.5 & 85.7 & 5.6 & 11 Aug & 14 & 21.9 & 21.6 \\
\hline RH II & 59.5 & 55.6 & 54.2 & 4.9 & 18 Aug & 21 & 20.9 & 19.6 \\
\hline SSH & 765 & 859.8 & 831.5 & 5.9 & 25 Aug & 28 & 16.7 & 17.6 \\
\hline RF & 508.9 & 351.4 & 134.7 & 56.6 & $1 \mathrm{Sep}$ & 35 & 16.3 & 15.6 \\
\hline GDD & 1325.6 & 1517.1 & 1527.4 & 7.8 & 8 Sep & 42 & 14.1 & 13.5 \\
\hline RTD & 3308.2 & 3435.3 & 3831.7 & 7.7 & $15 \mathrm{Sep}$ & 49 & 9.8 & 11.5 \\
\hline RHD & 4046.7 & 4773.9 & 4823.7 & 9.6 & $\begin{array}{l}\text { Chi-square } \\
\text { value }\end{array}$ & & 0.990 & \\
\hline ETC & 173.8 & 222.6 & 247.1 & 17.4 & \multicolumn{4}{|c|}{ Equation $Y(q / h a)=25.7-0.29 \times\left(R^{2}=0.96\right)$} \\
\hline
\end{tabular}


compared to 30.1 and $22.2{ }^{\circ} \mathrm{C}$ with normal weather. Increase of maximum and minimum temperatures $\left(0.02{ }^{\circ} \mathrm{C}\right)$ by climate change was reported by Jayakumar Varadan et al. (2017). The range of 0.4 to $3.1{ }^{\circ} \mathrm{C}$ ) of increase of maximum temperature was observed during cropping periods. However, increased maximum temperature is well in the range required for cotton. Hence, the changes of maximum temperatures by climate change may not have significantly influenced on growth and development of cotton as was evidenced by combined analysis data (Table 9). On the other hand, the increase of minimum temperatures observed with the range of 0.9 to $3.3{ }^{\circ} \mathrm{C}$ during cropping periods favoured growth and development of cotton, because of the fact that 50 years normal minimum temperatures is less than the optimum for cotton growth and development (Table 8 ). The early high rainfall received in the month of October (20142015) by climate change could be adapted by earlysown crop than late-sown crop. North-east monsoon crops are left to fend against flood risk during their initial stages by climate change (Jayakumar Varadan et al. 2017).The relative temperature disparity (RTD) is significantly and negatively correlated with seed cotton yield. The advance sowing of July (Table 8) had significantly lower mean of RTD (25.6) as compared to the corresponding 50 years normal in July (26.2). The growing degree day calculated revealed that the mean GDD is comparatively higher in the month of July (11.8) (experimental years) as compared to 50 years normal in July (10.6). The changes of weather parameters includes minimum temperature, GDD, and RTD observed in the month of July as compared to normal years, which were positive and conducive for crop growth and cotton production and thus ultimately favoured for shifting of optimum times of sowing of winter irrigated cotton from 15 August to 28 July.

\section{Yield prediction equation}

The prediction equation developed by multiple regression analysis is

$$
\begin{aligned}
& \text { Yield ( } \mathrm{q} / \mathrm{ha})=120.4-0.035 \text { RTD }(0-60 \text { days }) \\
& -0.039 \text { RTD }(61-130 \text { days })+0.019 \text { RHD }(61-130 \text { days }) \\
& +0.013 \operatorname{RF}(61-130 \text { days })-0.01 \text { SSH }(61-130 \text { days })
\end{aligned}
$$

The coefficients were significant (by considering $t$ and $p$ values) except SSH (61-130). The equation revealed that seed cotton yield was negatively correlated with RTD and positively correlated with RHD and rainfall. The yield prediction was done by using the Eq. (1) and, compared with observed values, found non-significant chisquare test values (estimated 0.9, tabulated value 37.65 ) (Fig. 3). The other regression equation

$$
\left(\text { equation } \mathrm{Y}(\mathrm{q} / \mathrm{ha})=25.7-0.29 \times\left(R^{2}=0.96\right)\right)
$$

was developed to study the relationship of times of sowing and yield loss (Table 10). The yield loss prediction was done by using Eq. (2) and, compared with observed values, found non-significant chi-square test values (estimated 0.9 , tabulated value 14.07 )

\section{Quality characters}

Increase in productivity alone could not benefit the cotton growers as quality of cotton fibre is the primary concern for fetching higher price. Lint samples analysed by HVI to assess on quality characters revealed that these were influenced little by genotypes (except strength (g/

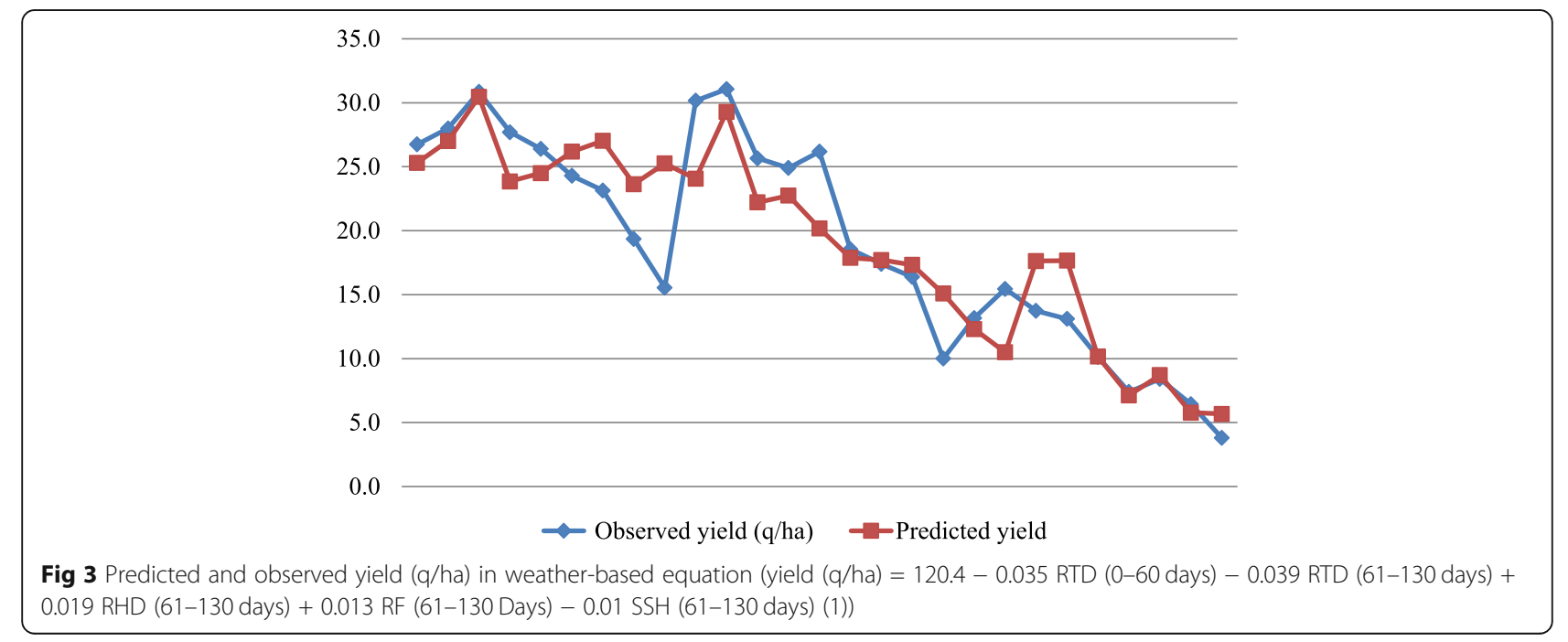


tex)) or planting time (Tables 6 and 7). The combined results revealed that Suraj had significantly higher fibre strength than Mallika BGII. The quality of characters had not been influenced significantly by different times of sowing (Sankaranarayanan et al. 2011a). In contrary to that, suboptimal weather conditions in late sowing reduced fibre quality parameters as reported by Gormus and Yucel (2002).

\section{Conclusion}

Sowing dates of cotton was restandardized as 21 July to 18 August for western zone of Tamil Nadu, India. Genotypes (Mallika BGII hybrid and Suraj non-Bt straight variety) recorded on par yield. Earlier studies showed that seed cotton yield decreased as the sowing was delayed/advanced from sowing date of 1 August to 31 August.

\section{Abbreviations \\ The quintal(q): 100 kg; GDP: Gross domestic product; Rs: Rupees; HVI: High- volume instrument; DTPA: Diethylene triamine penta acetic acid; EC: Electrical conductivity; GDD: Growing degree days; RTD: Relative temperature disparity; RH: Relative humidity; BG: Boll gaurd; DOS: Date of sowing; CD: Critical difference; SSH: Sunshine hours; N: Nitrogen; P: Phosphorus; K: Potassium; $\mathrm{dsm}^{-1}$ : Decisiemens per metre; LAl: Leaf area index; Y: Yield; ETC: Crop evapotranspiration}

\section{Acknowledgements}

The authors duly acknowledge the facilities and support provided by Technology Mission for Cotton and The Director, ClCR, Nagpur, Maharashtra, India.

\section{Authors' contributions}

SK-first author involved in planning, execution of field experiments, data collection on quality parameters, edaphic and reporting the data for article preparation. PAH—second author involved in data collection and interpretation of weather parameters. RK - third author involved in the field experiment and data collection and analysis. All authors read and approved for final manuscript

\section{Funding}

The study was funded by Technology Mission on Cotton, Mini Mission-I, Department of Agriculture and Cooperation, Ministry of Agriculture, Government of India, New Delhi.

\section{Availability of data and materials}

Weather data of experimental periods and data of individual experimental year are analysed and available with us.

\section{Ethics approval and consent to participate}

The project is aimed to find out the sowing window of cotton under climate changed situation. The experiment does not involve any component related to ethical and animal welfare issues. The bio safety is not applicable here.

\section{Consent for publication}

As authors, we express our willingness for the publication in the journal.

\section{Competing interests}

The authors declare that they have no competing interests

\section{Author details}

'ICAR-Central Institute for Cotton Research, Regional station, Coimbatore, Tamil Nadu 641003, India. ${ }^{2}$ Institute of Agriculture, National Pulses Research Centre, Tamil Nadu Agricultural University, Vamban 622303, India.
Received: 12 June 2020 Accepted: 17 August 2020

Published online: 04 September 2020

\section{References}

AICCIP (2009) Annual report of all India coordinated cotton improvement project, Coimbatore, 2008-09.

Ali M, Mohy-ud-din Q, Ali MA, Sabir S, Ali L (2004) Cotton yield as influenced by different sowing dates under the climatic conditions of Vehari-Pakistan. Int J Agric Biol 4:644-646

Balathandayutham K, Mayilswami C (2015) Effect of climate variability on crop productivity of Coimbatore District, Tamil Nadu. Trends Biosci 8(11):2850

Berger KC, Truog E (1939) Boron determination in soils and plants. Ind Eng Chem (AnalEd) 11:540-545

Bolonhezi AC, Justi MM, Oliveira RC (2000) Narrow spacing for varieties of herbaceous cotton (Gossypium hirsutum L.) plant development and retention of reproductive structures. Field Crop Res 53(5):611-613

Bradow JM, Davidonis GH (2000) Quantitation of fibre quality and the cotton production-processing interface: a physiologist's perspective. J Cotton Sci 4 34-64

Campbell BT, Jones MA (2005) Assessment of genotype X environment interactions for yield and fiber quality in cotton performance trials. Euphytica 144:69-78

Dason AA, Krishnasamy S, Ramakrishnan YS, Krishnadoss D (1996) Cotton growing environment Book published from Agricultural Research station, Kovilpatty-628 501 Tamil Nadu agricultural University, Coimbatore, India

Delo ZA, Laghari S, AbroSD KS (2012) Effect of sowing dates and picking intervals at boll opening percent, yield and fiber quality of cotton cultivars.Science and. Technol Develop J 31(3):288-293

Elayan ED, Ohair S, Abdalla AMA, Abdel-Gawad SD, Nadia A, Wageda F (2015) Effect of delaying planting date on yield, fiber and yarn quality properties in some cultivars and promising crosses of Egyptian cotton. Am Eur J Agric Environ Sci 15(5):754-763

Gopalswamy N, Palaniappan SP, Sankaran S (1988) Effect of heat units and solar radiation on the productivity of irrigated cotton. Proc. III. Indian Agro meteorology Congress, Kerala, pp 28-30

Gormus O, Yucel C (2002) Different planting date and potassium fertility effects on cotton yield and fiber properties in the Cukurova region, Turkey. Field Crops Research 78:141-149.

Gwathmey CO, Clement JD (2010) Alteration of cotton source - sink relations with plant population density and mepiquat chloride. Field Crop Res 116 101-107

Hussain M, Ahmad A, Zamir SI (2007) Evaluation of agro-qualitative characters of five cotton cultivars (Gossypium hirsutum L.) grown under different conditions. Pak J Agric Sci 44(4):575-580

Iwata F (1984) Heat unit concept of crop maturity. In: Gupta US (ed) Physiological aspects on dry land farming. Oxford and IBH, New Delhi, pp 351-370

Jackson ML (1973) Soil chemical analysis. Prentice Hall of India. Pvt. Ltd., New Delhi

Jayakumar Varadan R, Kumar P, Jha GK, Pal S, Singh R (2017) An exploratory study on occurrence and impact of climate change on agriculture in Tamil Nadu, India. Theor Appl Climatol 127:993-1010

Khan A, Najeeb U, Wang L, Tan DKY, Yang G, Munsif F, Ali S, Hafeez A (2017) Planting density and sowing date strongly influence growth and lint yield of cotton crops. Field Crop Res 209:129-135

Khan FUZ, Rehman SU, Ali MA, Waqas M, Chaudhry MH, Bilal M, Ghulam Q, Latif A, Ashraf J, Farhan U (2015) Exploitation of germplasm for plant yield improvement in cotton (Gossypium hirsutum L.). J Green Physiol Genet Genom 1:1-10

Lakkineni KC, Bhardwaj SN, Abrol YP (1994) Effect of temperature on early growth and seed yield in upland cotton (Gossypium hirsutumL.). Indian J Agric Sci 64: 653-654

Lindsay WL, Norvell WA (1978) Development of a DTPA soil test for zinc, iron, manganese, and copper. Soil Sci Soc Amer J 42:421-428

Liu J, Meng Y, Chen J, Lv F, Ma Y, Chen B, Oosterhuis DM (2015) Effect of late planting and shading on cotton yield and fiber quality formation. Field Crop Res 183:1-13

Olsen SR, Cole CV, Watanabe FS,Dean LA (1954) Estimation of available phosphorous in soil extraction with sodium bicarbonate. USDA (Cir.). p. 939.

Pettigrew WT (2002) Improved yield potential with an early planting cotton production system. Agron J 94:997-1003 
Pettigrew WT, Adamczyk JJ (2006) Nitrogen fertility and planting date effects on lint yield and Cry1Ac (Bt) endotoxin production. Agron J 98:691-697

Reddy KR (1992) Temperature effects on cotton fruit detention. Agron J 87:820826

Richards LA (1954) Diagnosis and improvement of saline and alkali soils. In: USDA Handbook 60. Dept. of Agriculture, United States

Sankaranarayanan K, Praharaj CS, Nalayini P, Bandyopadhyay KK, Gopalakrishnan N (2010) Climate change and its impact on cotton. Indian J Agric Sci 80(7): $561-575$

Sankaranarayanan K, Praharaj CS, Nalayini P, Gopalakrishnan N (2011a) Evaluation of Bt and non-Bt cotton hybrids under varied planting time. Indian J Agric Sci 56(1):68-73

Sankaranarayanan K, Praharaj CS, Nalayini P, Gopalakrishnan N (2011b) Growth, yield and quality of Bt cotton hybrid under varied planting patterns, NPK levels and season variations. Indian J Agric Sci 81(9): $871-874$

Saroya AR, Saeed M, Umar M (1980) Effect of different sowing dates on the yield of cotton (Gossypium hirsutum L). Pakistan Cotton 24:267-273

Subbiah BC, Asija GL (1956) A rapid procedure for the estimation of available nitrogen in soils. Curr Sci 25:259-260

Yeates SJ, Khal MF, Dougall AJ (2013) The impact of variable, cold minimum temperatures on boll retention, boll growth and yield recovery of cotton. $J$ Cott Sci 17:89-101

Zeng L, Jr WRM, Campbell BT, Dever JK, Zhang J, Glass KM, Jones AS, Myers GO, Bourland FM (2014) Breeding and genetics. Genotype-by-environment interaction effects on lint yield of cotton cultivars across major regions in the U.S. cotton belt. J Cott Sci 18:75-84.

Zhang D, Zhang L, Liu J, Han S, Wang Q, Evers J, Li L (2014) Plant density affects light interception and yield in cotton grown as companion crop in young jujube plantations. Field Crop Res 169:132-139

\section{Publisher's Note}

Springer Nature remains neutral with regard to jurisdictional claims in published maps and institutional affiliations.

\section{Submit your manuscript to a SpringerOpen ${ }^{\circ}$ journal and benefit from:}

- Convenient online submission

- Rigorous peer review

- Open access: articles freely available online

- High visibility within the field

- Retaining the copyright to your article

Submit your next manuscript at $\boldsymbol{\nabla}$ springeropen.com 